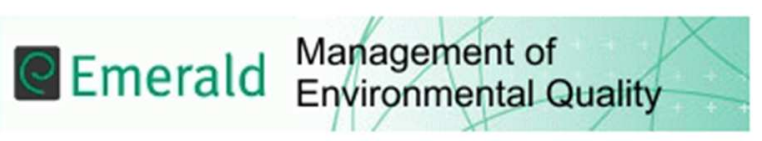

\title{
Environmental Health Indicators: A review of initiatives worldwide
}

\begin{tabular}{|r|l|}
\hline Journal: & Management of Environmental Quality \\
\hline Manuscript ID: & MEQ-11-2012-0075.R5 \\
\hline Manuscript Type: & Research Paper \\
\hline Keywords: & $\begin{array}{l}\text { Environmental health indicators, Climate change, Policy, Monitoring, } \\
\text { Evaluation, DPSEEA }\end{array}$ \\
\hline \multicolumn{2}{|l}{} \\
\hline
\end{tabular}

\section{SCHOLARONE \\ Manuscripts}




\section{Environmental Health Indicators: A review of initiatives worldwide}

Purpose: The extent to which research into the design and development of environmental health indicators (EHIS) has translated into operational programmes is unclear. The aims of this review were to identify EHI initiatives worldwide, distil the EHIs and draw lessons from the experience.

Approach: A systematic Internet-based review was undertaken. Programmes were selected for inclusion if they: 1) they had the ability to monitor both the physical environment and associated health outcomes; and 2) the parent agency had the ability to influence policies related to the environment and health.

Findings: The small number of eligible programmes indicates EHI initiatives are not yet well established, especially in developing countries. The use of indicators was also limited by uncertainties in the exposure-response relationships that they implied, and the consequent inability to translate the indicators into a common measure of health impact. In addition, there is no information on the extent to which the indicators have been applied in decision-making, nor on the policy implications of using indicators.

Practical implications: More effort is needed to encourage the development and use of more balanced and informative sets of indicators, and to evaluate their use and outcomes in terms of health benefits.

Value: The time is right for a substantial review paper on EHIs as they are now being used by a number of organisations and to our knowledge this is the first review of operational Environmental Health Indicator programmes worldwide.

Keywords: Environmental health indicators, climate change, policy, monitoring, evaluation, DPSEEA

Paper type: Literature review

\section{Introduction}

Reliable and consistent information on environment and health is essential, both to provide warning of emerging risks to health and to help shape, select between and monitor policy actions aimed at controlling exposures, preventing disease and minimising health disparities. The raw data to provide this information derives mainly from routine surveillance and monitoring. Data on their own, however, are often confusing and may provide only a partial perspective on the issues of concern. To support policy, therefore, they typically need to be linked and synthesised into some form of indicator. The concept of environmental indicators gained strength initially in response to the National Environmental Policy Act of 1969, in the United States of America, which called for the development of methods to evaluate environmental quality, as a basis for guiding decision-making (National Academy of Sciences, 1975, Liu, 1975). By the early 1980s, a number of national and international initiatives had been established to construct environmental indicators, as a basis for state of the environment reporting, and others were being proposed (Best, 1983, Healy, 1987, France and Briggs, 1980). At the same time, health indicators were being developed, motivated in part by the Health-for-All initiative of the World Health Organization (WHO) (1981). The merging of these concepts into that of 'environmental health indicators' (EHIs) occurred some ten years later, again under the auspices of the WHO (Corvalán et al., 1996, Kjellström and Corvalán, 1995).

EHIs have been defined as "an expression of the link between environment and health, targeted at an issue of specific policy or management concern and presented in a form which facilitates interpretation for effective decision-making" (Corvalán et al., 1996, pg 25). Underpinning this definition is the premise that EHIs reflect an explicit, causal association between one or more 
identifiable environmental exposures and one or more definable health outcomes. Given this association, two general types of EHI have been recognised: 'exposure-side indicators', which use information on exposures to imply degrees of health risk, or 'health-side indicators', which use information on health outcomes to suggest attributable effects (Briggs, 2003a).

A number of EHI sets have been proposed over the last 20 years (e.g. Briggs, 1999, Corvalán et al., 2000a, Briggs, 2003b), designed to serve a number of important purposes, for a range of different agencies, from the local to international to multinational levels (Phillips et al., 2001). Briggs (1999, pg 3) identified the following key purposes of EHIs:

- to monitor trends in the state of the environment, therefore identifying potential risks to human health

- to monitor trends in health outcomes that are linked to environmental hazards and exposures, can help guide policy formation

- to compare the environmental health status of geographic areas, in order to help target action and/or allocate resources

- to monitor the effectiveness of policies and other interventions on environmental health

- to help raise awareness about environmental health issues across different stake-holder groups (e.g. policy makers, industry, health practitioners, public and media)

- to help initiate further investigations into links between the environment and health (e.g. epidemiological studies), as a basis for informing health interventions and policy.

Although several researchers have usefully conceptualised EHIs and discussed aspects such as their general strengths and weaknesses and criteria for selecting indicators (Rice, 2003, Cairns et al., 1993) and adapted the Driving force-Pressure-State-Exposure-Effect-Action (DPSEEA) framework (Spiegel et al., 2001), much of this work has not led to the development of operational EHI programmes. Following the WHO's lead, considerable effort has gone on in recent years into developing initiatives to compile and use EHIs at both national and international levels. In the process, there has been extensive debate about the 'rules' for EHI development. The criteria proposed have not necessarily been mutually supportive. For example, it is argued that indicators should 'resonate' with their users, in that they are both readily interpretable and relevant to their needs. This, however, often vies with the need for scientific credibility - in particular that they represent a clear and plausible link between exposure and health outcome. Likewise, attempts are often made to ensure consistency with other, pre-existing indicator sets, since this facilitates comparisons between different areas, and thus helps to pool information and prioritise problems at higher policy levels. This, however, may make the indictors less relevant locally. Another important criterion is that the indicators provide a clear and balanced picture of the issues they represent, but this may be compromised by the practical need to rely on readily available data. For these reasons, agencies often struggle to come to terms with the notion of EHIs, and much duplication of effort occurs in trying to design and construct effective indicator sets.

Given this, there is a clear need to review recent experience in indicator development, in order to tease out the lessons that have been learned, and point towards good practice, where this exists. The aims of this review are thus to: 1) list and describe current indicator programmes at broad regional, national or international level; 2 ) identify the commonalities, gaps and inconsistencies in these programmes; 3 ) suggest future priorities for research and development of EHIs.

\section{Methods}

The review is restricted to operational EHI programmes - i.e. initiatives which involved not only the design and compilation of EHIs but also their regular reporting. In order to be eligible, the initiatives had to be developed by, or on behalf of, bodies with the ability to set policies governing either the environment or health care at a regional, national or international scale (i.e. local - e.g. 
municipal - initiatives were excluded, as were programmes conducted purely for exploratory purposes or by commercial agencies).

Initiatives were selected on the basis of a systematic Internet-based search. For this, we initially used the search engines PubMed and ScienceDirect, employing the key search terms 'environmental indicators', 'health indicators', 'environmental health indicators', and 'public health indicators'. The time period 1996-2010 was selected as this was considered to capture the key development period for EHIs, and the search was conducted in early 2011. Tellingly, this search yielded few peerreviewed publications in the scientific literature relating to existing initiatives. The search was therefore extended, using the Google and Google Scholar search engines. This revealed more information, in the form of policy documents and reports from the agencies responsible for developing and administering EHI programmes. Next, citations in papers and reports from these initial searches were followed up, leading to the identification of a second round of papers. Finally, contact was made by email with relevant national monitoring agencies in order to check for the existence of any initiatives that might have been missed in those regions for which no information had been discovered - including the WHO Regional Offices for Africa, Pan America, South-East Asia, and the Western Pacific.

EHIs within the resulting set of indicator programmes were classified into a series of categories, defined a priori (Table 1). These categories were specified because they were felt to represent the main environmental exposures and pathways of relevance for human health. Indicators were also classified as either 'exposure-side' or 'health-side' depending on their focus. Inevitably, some degree of judgement was needed in applying these classifications, and in some cases indicators could be assigned to more than one category. In these cases, we allocated the indicators to what seemed to be the most relevant category (e.g. based on the way the indicator had been used and interpreted in practice). We were interested only in health outcomes for which there was substantial evidence of a measurable association with defined environmental exposures; where such an association could not be defined, the indicator was excluded. Some programmes use the DPSEEA framework as a way of selecting and structuring EHIs (Corvalán et al., 1996). If the DPSEEA (or a similar) model was used by the programme, only state, exposure and effect indicators were included: i.e. more distal indicators were ignored. Lastly, if multiple EHIs had been developed by an organisation over a number of years, we used the most recent set. 
Table 1: Summary of categories

\begin{tabular}{|l|l|}
\hline Category & Sub-category \\
\hline Water and sanitation & $\begin{array}{l}\text { Exposure-side indicators } \\
\text { Health-side indicators }\end{array}$ \\
\hline Air quality & $\begin{array}{l}\text { Exposure-side indicators } \\
\text { Health-side indicators }\end{array}$ \\
\hline Climate and physical environment & $\begin{array}{l}\text { Exposure-side indicators } \\
\text { Health-side indicators }\end{array}$ \\
\hline Built environment & $\begin{array}{l}\text { Exposure-side indicators } \\
\text { Health-side indicators }\end{array}$ \\
\hline Food safety & Exposure-side indicators \\
\hline Biosecurity & $\begin{array}{l}\text { Exposure-side indicators } \\
\text { Health-side indicators }\end{array}$ \\
\hline
\end{tabular}

\section{Summary of existing EHI programmes}

Only five initiatives were identified that met the selection criteria. These comprised two multinational (North America and WHO Europe), two national (United States and New Zealand) and one state (Victoria, Australia) system. This is somewhat surprising, given the plethora of studies and reports that have either set out the case for $\mathrm{EHI}$ development, or outlined putative indicator sets (e.g. Corvalán et al., 1996, Corvalán et al., 2000a, Briggs, 1999, Briggs, 2003b, Ahmed et al., 2007, English et al., 2009). It suggests that relatively few of the exploratory and demonstration projects that have been undertaken have translated into operational systems, and begs the question of why.

The Environment and Health Information System (ENHIS) is a European initiative. It produces biennial indicator-based assessments for environment and health priorities for the European Region (World Health Organization Regional Office for Europe, 2010). The 22 indicators are presented as a series of fact sheets and follow a common template including information on the on the environment and health context, the policy relevance and context, as well as suggestions for further monitoring.

Two of the initiatives identified relate to North America. The Commission of Environmental Cooperation, in combination with a steering group, coordinates the development of indicators of children's health and the environment for Canada, Mexico and the United States (Commission for Environmental Cooperation, 2006). Where child-specific information cannot be sourced, it is common for results for the total population to be provided. So far, just one report has been produced. The National Environmental Public Health Tracking Network (Centers for Disease Control and Prevention, 2010b) (NEPHTN) is aimed at providing a national system that will integrate data relating to environmental hazards, human exposure and health effects for the entire age spectrum into a network of standardised electronic data. Indicators and thematic topics are continually being updated.

One national system was identified, in New Zealand. Here, EHI reporting is commissioned by the Ministry of Health and utilises data collected by a number of national agencies (Centre for Public Health Research and GeoHealth Laboratory, 2011). Where possible, regional data are incorporated giving a more geographically detailed account of the state of the environment and health outcomes. Fact sheets and report cards are updated as data becomes available.

In addition, one regional (state) level system - the indicator programme for the State of Victoria, Australia - was found. This produces biennial reports, aimed at providing a comprehensive picture of the health and wellbeing of Victorians and incorporating chapters on a variety of topics (Department of Human Services, 2008). Indicators from the 'health and environment' chapter were used in this review. 
1

2

3

4

5

6

7

8

9

10

11

12

13

14

15

16

17

18

19

20

21

22

23

24

25

26

27

28

29

30

31

32

33

34

35

36

37

38

39

40

41

42

43

44

45

46

47

48

49

50

51

52

53

54

55

56

57

58

59

60

Table 2 summarises the indicators from these initiatives. It should be noted that the descriptions of the indicators have usually been adapted from those used in the source documents, both to limit the length of the table and for purposes of consistency. Further details on each of the main categories, with reference to relevant initiatives/regions (in superscript), are given below. 
Table 2: Summary of environmental health indicators included in the five selected EHI initiatives

\begin{tabular}{|c|c|c|c|c|c|c|c|c|c|}
\hline Type of Indicator & Indicator & Measurement, Standards, and Thresholds & Eur & USA $*$ & Can & Mex & USA & NZ & Vic \\
\hline \multicolumn{10}{|c|}{ 1. WATER AND SANITATION } \\
\hline \multirow{12}{*}{$\begin{array}{l}\text { Exposure-side } \\
\text { indicators }\end{array}$} & $\begin{array}{l}\text { Sewerage system } \\
\text { access }\end{array}$ & $\begin{array}{l}\text { Percentage of the population served by }{ }^{1} / \text { not served by a } \\
\text { sewerage system } \\
\text { faii connected to a wastewater treatment } \\
\text { far a safe local wastewater disposal system }\end{array}$ & $x$ & & & $x$ & & & \\
\hline & \multirow{4}{*}{$\begin{array}{l}\text { Drinking-water } \\
\text { access }\end{array}$} & $\begin{array}{l}\text { Percentage of the population with access to safe } \\
\text { drinking-water at home } \\
1,4\end{array}$ & $\mathrm{x}$ & & & & & $\mathrm{x}$ & \\
\hline & & $\begin{array}{l}\text { Percentage }^{3 i} \text { or number of people }{ }^{2} \text { connected to }{ }^{2} / \text { not } \\
\text { connected to }^{3 i} \text { public water systems }\end{array}$ & & $\mathrm{x}$ & $\mathrm{x}$ & & & & \\
\hline & & Percentage of the population served by domestic wells ${ }^{2}$ & & $\mathrm{x}$ & & & & & \\
\hline & & Percentage of the population without potable water ${ }^{3 i i i}$ & & & & $\mathrm{x}$ & & & \\
\hline & \multirow{5}{*}{$\begin{array}{l}\text { Drinking-water } \\
\text { quality }\end{array}$} & $\begin{array}{l}\text { Percentage served by drinking-water supplies with zero } E \text {. } \\
\text { coli and zero (oo)cysts } / 100 \mathrm{~mL}^{4,6}\end{array}$ & & & & & & $\mathrm{x}$ & \\
\hline & & $\begin{array}{l}\text { Number of water sampling localities where } \geq 98 \% \text { of } \\
\text { drinking-water samples contain zero } E \text {. coli/ } 100 \mathrm{~mL}^{5}\end{array}$ & & & & & & & $\mathrm{x}$ \\
\hline & & $\begin{array}{l}\text { Number of towns with drinking-water fluoridation to 1 } \\
\mathrm{ppm}^{5}\end{array}$ & & & & & & & $\mathrm{x}$ \\
\hline & & $\begin{array}{l}\text { Percentage of children }{ }^{3 i, 8} \text { or population }{ }^{1} \text { served by public } \\
\text { water systems not meeting health-based drinking-water } \\
\text { standards }{ }^{1,3 i i, 8} \text { or drinking-water monitoring and reporting } \\
\text { requirements }{ }^{3 i i, 8}\end{array}$ & $\mathrm{x}$ & & & & $\mathrm{x}$ & & \\
\hline & & $\begin{array}{l}\text { Distribution of public water systems, number served, and } \\
\text { maximum and mean nitrate, arsenic, haloacetic acid and } \\
\text { trihalomethane concentrations of those systems }\end{array}$ & & $x$ & & & & & \\
\hline & \multirow{2}{*}{$\begin{array}{l}\text { Recreational water } \\
\text { quality }\end{array}$} & $\begin{array}{l}\text { Number }{ }^{4} \text { and percentage } \mathrm{e}^{1,4} \text { of samples with }>550^{4} \text { and } \\
<2000^{1} \text { E. coli/100mL (freshwater zones) }\end{array}$ & $\mathrm{x}$ & & & & & $\mathrm{x}$ & \\
\hline & & $\begin{array}{l}\text { Number and percentage of samples with }>280 \\
\text { enterococci } / 100 \mathrm{~mL} \text { (coastal zones) }\end{array}$ & & & & & & $\mathrm{x}$ & \\
\hline \multirow{6}{*}{$\begin{array}{l}\text { Health-side } \\
\text { indicators }\end{array}$} & \multirow{6}{*}{$\begin{array}{l}\text { Waterborne } \\
\text { disease }\end{array}$} & $\begin{array}{l}\text { Number of notifications of domestic campylobacteriosis, } \\
\text { cryptosporidiosis and giardiasis with untreated drinking- } \\
\text { water or recreational water exposure as risk factors }\end{array}$ & & & & & & $\mathrm{x}$ & \\
\hline & & $\begin{array}{l}\text { Incidence of laboratory-confirmed }{ }^{3,7} \text { or symptom- } \\
\text { defined }^{3 i i i} \text { giardiasis among children }\end{array}$ & & & $x$ & $\mathrm{x}$ & & & \\
\hline & & Percentage of cases of cholera among children ${ }^{3 i i}$ & & & & $\mathrm{x}$ & & & \\
\hline & & Mortality rate from diarrheic diseases in children ${ }^{3 i i i}$ & & & & $x$ & & & \\
\hline & & $\begin{array}{l}\text { Number of waterborne disease outbreaks attributable to } \\
\text { drinking-water and bathing water each year }{ }^{1}\end{array}$ & $\mathrm{x}$ & & & & & & \\
\hline & & $\begin{array}{l}\text { Number of waterborne disease outbreaks by type of } \\
\text { drinking-water system }\end{array}$ & & & & & $\mathrm{x}$ & & \\
\hline \multicolumn{10}{|l|}{ 2. AIR QUALITY } \\
\hline \multirow{12}{*}{$\begin{array}{l}\text { Exposure-side } \\
\text { indicators }\end{array}$} & \multirow{5}{*}{$\begin{array}{l}\text { Particulate Matter } \\
(\mathrm{PM})_{10}\end{array}$} & $\begin{array}{l}\text { Percentage of children living in areas not meeting the 24- } \\
\text { hour average } \mathrm{PM}_{10} \text { standard }^{3 \mathrm{ii}, 10} \text { of } 150 \mu \mathrm{g} / \mathrm{m}^{3}\end{array}$ & & & & & $\mathrm{x}$ & & \\
\hline & & $\begin{array}{l}\text { Number of days not meeting the 24-hour average } \mathrm{PM}_{10} \\
\text { standard }{ }^{4,5} \text { of } 50 \mu \mathrm{gg} / \mathrm{m}^{3}\end{array}$ & P & & & & & $\mathrm{x}$ & $\mathrm{x}$ \\
\hline & & $\begin{array}{l}\text { Percentage of days the air quality index for 24-hour } \\
\text { average } \mathrm{PM}_{10} \text { is very good, good, fair, poor, or very poor }\end{array}$ & & P & & & & & $x$ \\
\hline & & $\begin{array}{l}\text { Number of days not meeting the annual average } \mathrm{PM}_{10} \\
\text { standard }{ }^{4} \text { of } 20 \mu \mathrm{g} / \mathrm{m}^{3}\end{array}$ & & & & & & $\mathrm{x}$ & \\
\hline & & Population-weighted annual average $\mathrm{PM}_{10}$ concentration ${ }^{1}$ & $\mathrm{x}$ & & & & & & \\
\hline & \multirow{4}{*}{$\mathrm{PM}_{2.5}$} & $\begin{array}{l}\text { Percentage of children living in areas } 3 \mathrm{~s}^{3 i, 10}, \text { percentage of } \\
\text { days and number of person-days } \mathrm{s}^{2,8} \text { not meeting the } 24- \\
\text { hour average } \mathrm{PM}_{2.5} \text { standard of } 35 \mu \mathrm{g} / \mathrm{m}^{3}\end{array}$ & & $\mathrm{x}$ & & & $x$ & & \\
\hline & & $\begin{array}{l}\text { Percentage of days the air quality index for } 24 \text {-hour } \\
\mathrm{PM}_{2.5}\left(25 \mu \mathrm{g} / \mathrm{m}^{3}\right) \text { is very good, good, fair, poor, or very } \\
\text { poor }^{5}\end{array}$ & & & & & & & $x$ \\
\hline & & $\begin{array}{l}\text { Percentage living in areas not meeting the annual } \\
\text { average } \mathrm{PM}_{2.5} \text { standard }{ }^{2,3 i 1,8} \text { of } 15 \mathrm{\mu g} / \mathrm{m}^{3}\end{array}$ & & $x$ & & & $\mathrm{x}$ & & \\
\hline & & Annual average $\mathrm{PM}_{2.5}$ concentrations ${ }^{2,8}$ & & $\mathrm{x}$ & & & & & \\
\hline & \multirow[b]{2}{*}{$\begin{array}{l}\text { Carbon monoxide } \\
\text { (CO) }\end{array}$} & $\begin{array}{l}\text { Percentage of children living in areas not meeting the 1- } \\
\text { hour average } \mathrm{CO} \text { standard }{ }^{\mathrm{ii}, 10} \text { of } 40 \mathrm{mg} / \mathrm{m}^{3}\end{array}$ & & & & & $\mathrm{x}$ & & \\
\hline & & $\begin{array}{l}\text { Number of times }{ }^{4} \text { and percentage of children living in } \\
\text { areas }{ }^{3 i i, 10} \text { not meeting the } 8 \text {-hour average CO standard of } \\
10 \mathrm{mg} / \mathrm{m}^{3}\end{array}$ & & & & & $x$ & $\mathrm{x}$ & \\
\hline & Nitrogen Dioxide & Number of times not meeting the 1-hour average $\mathrm{NO}_{2}$ & & & & & & $\mathrm{X}$ & \\
\hline
\end{tabular}


2

3

4

5

6

7

8

9

\begin{tabular}{|c|c|c|c|c|c|c|c|c|c|}
\hline & $\left(\mathrm{NO}_{2}\right)$ & standard $^{4}$ of $200 \mu \mathrm{g} / \mathrm{m}^{3}$ & & & & & & & \\
\hline & $\begin{array}{l}\text { Sulphur Dioxide } \\
\left(\mathrm{SO}_{2}\right)\end{array}$ & $\begin{array}{l}\text { Number of times not meeting the 1-hour average } \mathrm{SO}_{2} \\
\text { standard }{ }^{4} \text { of } 350 \mu \mathrm{g} / \mathrm{m}^{3}\end{array}$ & & & & & & $x$ & \\
\hline & Lead & $\begin{array}{l}\text { Percentage of children living in areas not meeting the } \\
\text { rolling 3-month average lead standard }{ }^{3 i i,} 10 \text { of } 0.15 \mu \mathrm{g} / \mathrm{m}^{3}\end{array}$ & & & & & $x$ & & \\
\hline & & $\begin{array}{l}\text { Number of days not meeting the 1-hour average } \mathrm{O}_{3} \\
\text { standard }{ }^{5} \text { of } 0.10 \mathrm{ppm} \text { and the } 4 \text {-hour average } \mathrm{O}_{3} \\
\text { standard }{ }^{5} \text { of } 0.08 \mathrm{ppm}\end{array}$ & & & & & & & $x$ \\
\hline & $\begin{array}{l}\text { Ozone } \\
\left(\mathrm{O}_{3}\right)\end{array}$ & $\begin{array}{l}\text { Percentage of days the air quality index for } 4 \text {-hour } \mathrm{O}_{3} \text { is } \\
\text { very good, good, fair, poor, very poor }\end{array}$ & & & & & & & $x$ \\
\hline & & $\begin{array}{l}\text { Percentage of children living in areas }{ }^{3 i, 10} \text {, percentage of } \\
\text { days and number of person-days }{ }^{2,8} \text { not meeting the 8- } \\
\text { hour average } \mathrm{O}_{3} \text { standard of } 0.075 \mathrm{ppm}\end{array}$ & & $x$ & & & $x$ & & \\
\hline & Visibility reducing & $\begin{array}{l}\text { Number of days not meeting the 1-hour visibility } \\
\text { standard }{ }^{5} \text { of at least } 20 \mathrm{~km}\end{array}$ & & & & & & & $\mathrm{x}$ \\
\hline & particles & $\begin{array}{l}\text { Percentage of days per year the air quality index for daily } \\
\text { visibility is very good, good, fair, poor, and very poor }\end{array}$ & & & & & & & $x$ \\
\hline & Second-hand & $\begin{array}{l}\text { Percentage of children }{ }^{1,3 i i, 3 i i i, 4} \text { and non-smoking adults }{ }^{4} \\
\text { exposed to second-hand smoke in the home }\end{array}$ & $\mathrm{x}$ & & $\mathrm{x}$ & & $x$ & $x$ & \\
\hline & smoke & $\begin{array}{l}\text { Percentage of smoke-free households with dependent } \\
\text { children }^{5}\end{array}$ & & & & & & & $x$ \\
\hline & & $\begin{array}{l}\text { Percentage of fuel wood users that use coal or wood as a } \\
\text { source of fuel for heating }\end{array}$ & & & & $x$ & & & \\
\hline & $\begin{array}{l}\text { Heating/fuel } \\
\text { source }\end{array}$ & $\begin{array}{l}\text { Percentage of children living in households using coal, } \\
\text { wood or dung as the main source of heating and cooking } \\
\text { fuel }^{1}\end{array}$ & $x$ & & & & & & \\
\hline & $\begin{array}{l}\text { Cooling water } \\
\text { tower quality }\end{array}$ & $\begin{array}{l}\text { Percentage of cooling water tower samples positive for } \\
\text { Legionella (threshold limit of detection is } 10 \\
\text { Legionella/mL) }\end{array}$ & & & & & & & $x$ \\
\hline & & $\begin{array}{l}\text { Percentage of cooling water tower samples }>10,000 \\
>100,000 \text { and }>500,000 \mathrm{cfu} / \mathrm{mL} \text { for } \mathrm{HCC}^{5}\end{array}$ & & & & & & & $x$ \\
\hline & Blood cotinine & $\begin{array}{l}\text { Percentage of children with levels of blood cotinine } \geq 0.05 \\
\mathrm{ng} / \mathrm{mL}^{3 i i}\end{array}$ & & & & & $x$ & & \\
\hline & CO poisoning & $\begin{array}{l}\text { Number }^{2,5} \text { and rate }{ }^{2} \text { of unintentional }\left.\right|^{2,5} \text { and unknown }{ }^{2} \mathrm{CO} \\
\text { poisoning emergency department visits }{ }^{2} \text { and hospital } \\
\text { admissions }^{5}\end{array}$ & & $x$ & & & & & $x$ \\
\hline & Legionellosis & $\begin{array}{l}\text { Number of notified cases of confirmed and probable } \\
\text { legionellosis and number of cases associated with } \\
\text { outbreaks }\end{array}$ & & & & & & & $x$ \\
\hline & & $\begin{array}{l}\text { Incidence of acute respiratory infections among } \\
\text { children }^{\text {3iii }}\end{array}$ & & & & $x$ & & & \\
\hline Health-side & Respiratory disease & $\begin{array}{l}\text { Hospitalisations }{ }^{4} \text { and deaths } s^{1,4,9} \text { for respiratory disease } \\
\text { (ICD-10 codes J00-J99) in children }{ }^{1,4} \text { and adults }\end{array}$ & $x$ & & & & & $\mathrm{x}$ & \\
\hline & & $\begin{array}{l}\text { Prevalence rates of asthma (wheezing or whistling in the } \\
\text { chest in the past } 12 \text { months) and allergic } \\
\text { rhinoconjunctivitis (sneezing or a runny or blocked nose } \\
\text { accompanied by itchy watery eyes in the absence of a } \\
\text { cold or the flu) in children }{ }^{1}\end{array}$ & $x$ & & & & & & \\
\hline & Asthma & $\begin{array}{l}\text { Prevalence of physician-diagnosed asthma (ever) among } \\
\text { children }^{3 \mathrm{i}}\end{array}$ & & & $x$ & & & & \\
\hline & & Incidence of asthma among children ${ }^{3 i i i}$ & & & & $\mathrm{X}$ & & & \\
\hline & & $\begin{array}{l}\text { Percentage of children with asthma (ever had asthma, } \\
\text { currently have asthma, had asthma or asthma attack in } \\
\text { last } 12 \text { months) }\end{array}$ & & & & & $x$ & & \\
\hline & & Hospitalisation rate for asthma (ICD-9-CM: 493$)^{2}$ & & $\mathrm{x}$ & & & & & \\
\hline 3. CLIMATE AN & CAL ENVIRONMENT & & & & & & & & \\
\hline & & $\begin{array}{l}\text { Number of hot days (maximum temperature of } \geq 35^{\circ} \mathrm{C} \text { ) } \\
\text { and hot nights (minimum temperature } \geq 20^{\circ} \mathrm{C} \text { ) } / \text { year }^{5}\end{array}$ & & & & & & & $x$ \\
\hline & $\begin{array}{l}\text { Temperature } \\
\text { distribution }\end{array}$ & $\begin{array}{l}\text { Daily estimates of maximum temperature and heat index } \\
\text { for summer months }{ }^{2}\end{array}$ & & $x$ & & & & & \\
\hline & & Percentage of adults with diabetes ${ }^{2}$ & & $\mathrm{X}$ & & & & & \\
\hline Exposure-side & Heat vulnerability & $\begin{array}{l}\text { Hospitalisation rate for heart disease among adults aged } \\
65 \text { years and older }\end{array}$ & & $x$ & & & & & \\
\hline & & $\begin{array}{l}\text { Cumulative forest fire danger index (combination of } \\
\text { drought, air temperature, wind speed, and relative } \\
\text { humidity)/year }\end{array}$ & & & & & & & $x$ \\
\hline & $\begin{array}{l}\text { Daily ultraviolet } \\
\text { radiation levels }\end{array}$ & $\begin{array}{l}\text { Distribution of reported UV Index days (exposure } \\
\text { category 'extreme' }=\text { UV index } 11+\text {, 'very high' }=8 \text { to } 10 \text {, } \\
\text { 'high' }=6 \text { to } 7, \text { 'moderate' }=3 \text { to } 5 \text {, and 'low' }=2 \text { or }\end{array}$ & & & & & & & $x$ \\
\hline
\end{tabular}




\begin{tabular}{|c|c|c|c|c|c|c|c|c|c|}
\hline & & below), by season ${ }^{5}$ & & & & & & & \\
\hline \multirow{2}{*}{$\begin{array}{l}\text { Health-side } \\
\text { indicators }\end{array}$} & $\begin{array}{l}\text { Incidence of } \\
\text { melanoma }\end{array}$ & $\begin{array}{l}\text { Incidence of melanoma (ICD-10 codes C43, D03) in the } \\
\text { population aged }<55 \text { years }{ }^{1}\end{array}$ & $x$ & & & & & & \\
\hline & $\begin{array}{l}\text { Heat related } \\
\text { mortality }\end{array}$ & $\begin{array}{l}\text { Number of heat related deaths (ICD-10 codes X30, T67) } \\
\text { for summer months }{ }^{2}\end{array}$ & & $\mathrm{x}$ & & & & & \\
\hline \multicolumn{10}{|c|}{ 4. BUILT ENVIRONMENT } \\
\hline \multirow{6}{*}{$\begin{array}{l}\text { Exposure-side } \\
\text { indicators }\end{array}$} & $\begin{array}{l}\text { Radon levels in } \\
\text { dwellings }\end{array}$ & $\begin{array}{l}\text { Estimated annual mean radon levels in dwellings and } \\
\text { percentage }{ }^{1} \text { with levels }>200 \text { and }>400 \mathrm{~Bq} / \mathrm{m}^{3}\end{array}$ & $x$ & & & & & & \\
\hline & $\begin{array}{l}\text { Homes with } \\
\text { problems of } \\
\text { dampness }\end{array}$ & $\begin{array}{l}\text { Percentage of the population living in homes with self- } \\
\text { reported problems of dampness such as leaking roof, } \\
\text { damp walls/floors/foundation or rot in window frames or } \\
\text { floor }^{1}\end{array}$ & $\mathrm{x}$ & & & & & & \\
\hline & \multirow{3}{*}{$\begin{array}{l}\text { Homes with } \\
\text { potential lead } \\
\text { hazards }\end{array}$} & Number of pottery workshops per state ${ }^{3 i i i}$ & & & & $\mathrm{X}$ & & & \\
\hline & & $\begin{array}{l}\text { Percentage of houses with lead based paint and } \\
\text { percentage of houses that have lead contamination in the } \\
\text { house or soil around the house, above EPA standards }\end{array}$ & & & & & $x$ & & \\
\hline & & $\begin{array}{l}\text { Percentage of children living in homes built prior to } 1960 \\
\text { 3i or percentage of homes built before } 1950 \text { or between } \\
1950 \text { and } 1979^{2}\end{array}$ & & $\mathrm{x}$ & $x$ & & & & \\
\hline & $\begin{array}{l}\text { Physically active } \\
\text { children }\end{array}$ & $\begin{array}{l}\text { Percentage of children who exercise } 60 \text { minutes per day } \\
\text { at least } 5 \text { days per week }{ }^{1}\end{array}$ & $\mathrm{x}$ & & & & & & \\
\hline \multirow{5}{*}{$\begin{array}{l}\text { Health-side } \\
\text { indicators }\end{array}$} & Blood lead levels & Distribution of blood lead levels in children ${ }^{1,3}$ & $\mathrm{X}$ & & $\mathrm{X}$ & $\mathrm{X}$ & $\mathrm{x}$ & & \\
\hline & $\begin{array}{l}\text { Road traffic } \\
\text { injuries }\end{array}$ & $\begin{array}{l}\text { Road traffic injury mortality rates for people aged }<25 \\
\text { years }^{1}\end{array}$ & $x$ & & & & & & \\
\hline & $\begin{array}{l}\text { Overweight or } \\
\text { obese children }\end{array}$ & $\begin{array}{l}\text { Percentage of children who are overweight (BMI of } \geq 25.0 \\
\mathrm{~kg} / \mathrm{m}^{2} \text { ) or obese }\left(\mathrm{BMI} \geq 30.0 \mathrm{~kg} / \mathrm{m}^{2}\right)^{1}\end{array}$ & $\mathrm{x}$ & & & & & & \\
\hline & $\begin{array}{l}\text { Unintentional } \\
\text { injuries (excluding } \\
\text { traffic accidents) }\end{array}$ & $\begin{array}{l}\text { Mortality rates for children aged } 1-19 \text { years for falls (ICD } \\
\text { 10: W00-W19), drowning (ICD 10: W65-W74), fires (ICD } \\
\text { 10: X00-X09) and poisoning (ICD 10: X40-X49) }\end{array}$ & $\mathrm{x}$ & & & & & & \\
\hline & $\begin{array}{l}\text { Occupational } \\
\text { injuries }\end{array}$ & $\begin{array}{l}\text { Incidence rate of non-fatal work injuries resulting in more } \\
\text { than three days of absence from work among those aged } \\
<18 \text { and } 18-24 \text { years }^{1}\end{array}$ & $x$ & & & & & & \\
\hline \multicolumn{10}{|c|}{ 5. FOOD SAFETY } \\
\hline \multirow{3}{*}{$\begin{array}{l}\text { Exposure-side } \\
\text { indicators }\end{array}$} & $\begin{array}{l}\text { Contaminants in } \\
\text { food }\end{array}$ & $\begin{array}{l}\text { Percentage of fruits, vegetables and grains with } \\
\text { detectable residues of organophosphate pesticides }{ }^{3 i, 3 i i, 8}\end{array}$ & & & $\mathrm{x}$ & & $\mathrm{x}$ & & \\
\hline & $\begin{array}{l}\text { Dietary intake of } \\
\text { selected } \\
\text { contaminants }\end{array}$ & $\begin{array}{l}\text { Estimated dietary intake of selected contaminants from } \\
\text { the Global Environmental Monitoring System/Food } \\
\text { database }^{1}\end{array}$ & $x$ & & & & & & \\
\hline & $\begin{array}{l}\text { Contaminants in } \\
\text { human milk }\end{array}$ & $\begin{array}{l}\text { Concentrations of selected persistent organic pollutants } \\
\text { in human milk }\end{array}$ & $x$ & & & & & & \\
\hline \multicolumn{10}{|c|}{ 6. BIOSECURITY } \\
\hline $\begin{array}{l}\text { Exposure-side } \\
\text { indicators }\end{array}$ & $\begin{array}{l}\text { Disease-vector } \\
\text { species distribution }\end{array}$ & $\begin{array}{l}\text { Distribution and status of potential disease-vector } \\
\text { species }^{4}\end{array}$ & & & & & & $x$ & \\
\hline \multirow[t]{2}{*}{$\begin{array}{l}\text { Health-side } \\
\text { indicators }\end{array}$} & $\begin{array}{l}\text { Vector-borne } \\
\text { disease } \\
\text { notifications }\end{array}$ & $\begin{array}{l}\text { Number of notifications of vector-borne diseases } \\
\text { (includes malaria, dengue fever, rickettsial disease, Ross } \\
\text { River fever, cysticercosis, Barmah Forest virus, } \\
\text { Chikungunya fever, Japanese encephalitis and Lyme } \\
\text { disease) }\end{array}$ & & & & & & $\mathrm{x}$ & \\
\hline & $\begin{array}{l}\text { Overseas } \\
\text { outbreaks of } \\
\text { notifiable disease }\end{array}$ & $\begin{array}{l}\text { Worldwide distribution of key emerging and re-emerging } \\
\text { infectious and notifiable diseases of significant interest } \\
\text { reported to the } \mathrm{WHO}^{4}\end{array}$ & & & & & & $\mathrm{x}$ & \\
\hline
\end{tabular}

Notes:

United States* = National Public Health Tracking Network programme, as opposed to,

United States $=$ Comission for Environmental Cooperation programme

References 1 to 5 represent the programmes from which indicator details were obtained, as specified (with abbreviations used in the text), below.

${ }^{1}$ Europe (Eur) (World Health Organization Regional Office for Europe, 2010)

2 United States* (USA*) (Centers for Disease Control and Prevention, 2010a)

${ }^{3}$ North America (NA); ${ }^{3 \mathrm{i}}=$ Canada (Can) ${ }^{3 \mathrm{ii}}=$ United States (USA) ${ }^{3 \mathrm{iii}}=$ Mexico (Mex) (Commission for Environmental Cooperation, 2006)

4 New Zealand (NZ) (Ministry of Health, 2009)

${ }^{5}$ Victoria, Australia (Vic) (Department of Human Services, 2008)

References 6 to 10 provide additional information regarding the measures and thresholds used for these programmes

6 Ministry of Health (2005) 
7 Public Health Agency Canada (19 November 2010)

${ }^{8}$ United States Environmental Protection Agency (2010b)

9 Egorov (2010)

10 United States Environmental Protection Agency (2010a)

\section{Water and sanitation}

The presence of pathogens and chemical contaminants in drinking and bathing waters can result in a wide range of health effects. All EHI programmes reviewed included at least one exposure-side indicator for drinking-water. Drinking-water access was primarily measured in terms of the percentage of population with access to public water systems. In terms of drinking-water quality two initiatives ${ }^{\mathrm{NZ} \text {, Vic }}$ use 'zero $E$. coli per $100 \mathrm{~mL}^{\prime}$ as the standard for bacteria compliance with one-off indicators for protozoal ${ }^{\mathrm{NZ}}$, and a range of chemical contaminants ${ }^{\mathrm{USA}}$, USA ${ }^{*}$, Vic . Two E. coli based indicators were used for recreational water quality, based on different thresholds ${ }^{\text {Eur, } \mathrm{NZ}}$ and measurement techniques (percentage of samples and percentage of bathing waters). An additional coastal water quality indicator was applied by one initiative ${ }^{\mathrm{NZ}}$ based on enterococci thresholds. Two initiatives ${ }^{\mathrm{Eur}, \mathrm{Mex}}$ also monitored sewage system access, measured as the percentage of households connected.

In terms of health outcomes, almost all programmes ${ }^{\mathrm{Eur}, \mathrm{NA}, \mathrm{NZ}}$ included an indicator for waterborne disease incidence, with one programme ${ }^{\text {Mex }}$ also using a mortality indicator. Incidence of giardiasis was a common health outcome measure ${ }^{\mathrm{Can}, \mathrm{Mex}, \mathrm{NZ}}$ with some programmes additionally reporting on cryptosporidiosis $^{\mathrm{NZ}}$, campylobacteriosis $^{\mathrm{NZ}}$ and cholera ${ }^{\mathrm{Mex}}$. Two programmes ${ }^{\mathrm{Eur}, \mathrm{NZ}}$ involved estimation of health outcomes attributed to drinking-water or recreational water exposure, whereas the other programmes could not exclude other routes of transmission, such as via food or fomite.

\section{Air quality}

Exposure to both outdoor and indoor air pollutants is associated with exacerbation of asthma and other respiratory diseases. For outdoor air exposure indicators, approximately half of the programmes report 24-hour $\mathrm{PM}_{10}$ exposure, primarily represented as percentage of days not meeting standards ${ }^{\mathrm{NZ} \text {, Vic }}$ or percentage of children living in areas not meeting standards ${ }^{\text {USA }}$. Two initiatives ${ }^{\mathrm{Eur}, \mathrm{NZ}}$ included indicators assessing annual exposure. $\mathrm{PM}_{2.5}$ was also a relatively popular outdoor air pollutant to report, with both 24 -hour exposure ${ }^{\text {Vic, USA, USA* }}$ and annual exposure USA, USA* $^{*}$ thresholds included. Ozone was reported by three initiatives, and a range of averaging times were used: 1-hour Vic, 4-hour Vic and 8-hour USA*, USA. Exposure indicators for other outdoor pollutants such as carbon monoxide ${ }^{\mathrm{USA}, \mathrm{NZ}}$, nitrogen dioxide ${ }^{\mathrm{NZ}}$, sulphur dioxide ${ }^{\mathrm{NZ}}$, visibility reducing particles ${ }^{\mathrm{Vic}}$ and lead ${ }^{\mathrm{USA}}$ were reported by only one or two initiatives. The indicators were most commonly expressed in terms of the number exceedences, as opposed to a measure of population exposure.

In terms of indoor air, almost all programmes ${ }^{\mathrm{Eur}, \text { Can, USA, NZ }}$ reported the percentage of children exposed to second-hand smoke in the home or percentage of smoke-free households ${ }^{\text {Vic }}$. Two programmes Eur, Mex included household use of wood or coal as a fuel source indicator, and one programme ${ }^{\text {Vic }}$ reported the percentage of cooling water tower samples positive for Legionella. Three health-side incidence indicators related to specific exposures; carbon monoxide poisoning ${ }^{\text {USA*, Vic }}$ (although this relates to indoor carbon monoxide exposure which is different to the outdoor exposure indicator which is listed in this review), blood cotinine levels ${ }^{\text {USA }}$ related to secondhand smoke exposure, and cases of legionellosis and associated outbreaks resulting from Legionella exposure ${ }^{\text {Vic }}$. The remaining health-side indicators for air quality are not attributed to a particular exposure. Three initiatives have indicators for respiratory disease morbidity or mortality (two use the same ICD-10 grouping ${ }^{\mathrm{Eur}, \mathrm{NZ}}$; the other does not specify $\left.{ }^{\mathrm{Mex}}\right)$. Several indicators are used for asthma resulting from poor air quality ${ }^{\text {Uur, USA }^{*}, \mathrm{NA}}$, typically representing the severity of disease (such as self-reported symptoms, physician diagnosis, and hospitalisation). 
Climate and physical environment

Climate and other physical (i.e. natural) hazards indicators were reported by three initiatives and were dominated by exposure-side indicators. A suite of heat vulnerability indicators for climate change are reported ${ }^{\mathrm{UA}^{*}}$ including certain groups of people who are at increased risk for heat stress and death from extreme heat, population density and land cover. Measures focused on extent, in terms of percentage of population or area affected. Frequency measures of temperature distribution were also reported. A frequency measure of ultraviolet radiation levels ${ }^{\mathrm{Vic}}$ and melanoma incidence ${ }^{\text {Eur }}$ were reported, interestingly, by different initiatives.

\section{Built environment}

The built environment encompasses buildings and spaces that are created or modified by people and include all the spaces in which people live and work (Rao et al., 2007). The scale can range from individual homes up to neighbourhoods and cities. The design, availability and maintenance of the built environment, including such things as transport networks and public spaces, can affect health outcomes and behaviours. Several different thematic indicators were reported by the initiatives; the only one in common was lead exposure ${ }^{\mathrm{USA} A^{*}, \mathrm{NA}}$, typically measured as percentage of children living in houses built during a certain time period. A number of initiatives ${ }^{\mathrm{Eur}, \mathrm{NA}}$ also included the distribution of blood lead levels as a proxy disease severity indicator. Homes with problems of dampness, radon levels and physical activity were other exposure-side indicators ${ }^{\text {Eur. }}$. Health-side indicators such as road traffic, unintentional and occupational injuries and overweight and obese children were reported ${ }^{\mathrm{Eur}}$ but the relevant exposure-side indicators were generally not included.

\section{Food safety}

Few indicators were included for food safety and all focused on chemical hazards. These were reported by two initiatives as the percentage of selected food items with residues of organophosphate pesticides ${ }^{\mathrm{Can}, \mathrm{USA}}$, and in another as the dietary intake of selected contaminants and concentrations of persistent organic pollutants in human milk ${ }^{\mathrm{Eur}}$.

\section{Biosecurity}

Biosecurity refers to the exclusion, eradication and control of risks from organisms threatening the economy, environment and people's health (Biosecurity Council, 2003). It is an emerging area of interest, particularly because human activities such as travel and trade can play a pivotal role in the spread of infectious disease and pandemics. One initiative ${ }^{\mathrm{NZ}}$ reported biosecurity indicators: one exposure-side indicator relating to the geographic extent of exotic mosquito species and two healthside indicators measuring the extent of national vector-borne disease incidence and global distribution of infectious and notifiable diseases of significant interest

\section{Discussion}

The EHI programmes selected in this review comprise five initiatives: two at international level, two at national, and one at regional (state) level. While few in number, they represent all the eligible initiatives identified from a systematic web search, and whilst some programmes may inevitably have been missed - because descriptive information has not been widely published - they probably give a balanced view of the way in which EHIs are being used to support policy at these levels at the present.

Several features of these programmes merit note. One of these is the limited scope of most of the indicators, both in terms of the issues that they address and, within these, the specific phenomena to which they relate. As Table 2 shows, the main themes covered in all programmes are water and sanitation and air pollution. The former is targeted mainly at drinking water quality, with 
few indicators relating either to sewerage/sanitation or recreational waters. The most widely reported air pollutant is particulates (albeit for different size fractions), with fewer indicators relating to $\mathrm{NO}_{2}, \mathrm{SO}_{2}, \mathrm{O}_{3}$ and other pollutants. Differences are evident in many cases in the detailed definition of the indicators - e.g. the averaging times and thresholds - usually reflecting variations in the standards in different countries. Aspects of the built environment are considered to a lesser extent, notwithstanding the fact that people spend the majority of their time indoors, with exposures to second hand smoke being the most widely used indicator. Food safety and biosecurity also attract relatively little attention, while climate is included in only about half the indicator sets, and other physical hazards not at all.

To some degree, these emphases reflect the real health risks that exist in the areas covered by the programmes. The relatively limited attention given to risks such traffic accidents, drowning or nutritional factors (including obesity) nevertheless implies a somewhat restricted view of what counts as 'environmental', and acts to mask the way in which the physical environment interacts, almost inseparably, with human behaviour to determine health outcome. It also tends to ignore the powerful role policy-makers have in shaping the living environment of people, for both ill and good, and may therefore weaken the message to decision-makers in relevant areas of structural policies (e.g. transport, agriculture, planning) that they have a crucial part to play in protecting human health.

Another clear bias is towards exposure-, as opposed to health-side, indicators: approximately twice as many in these five programmes. Because detailed information on the rationale for the choice and range of indicators is rarely available, the reasons for this can again only be surmised. In part, it may reflect no more than availability of data: EHI programmes are not only reliant on existing monitoring and survey data, but may also make use of indicators that have already been developed by sister agencies. Since both monitoring and indicators tend to be rather better established in the area of environmental policy than they are health, this may mean that there is greater opportunity for the offer, or provision, of exposure-side measures. It is also possible, however, that the emphasis on exposure-side indicators is deliberate, because a major motive for EHIs is to make policy more preventative, and exposure-based indicators can give an earlier warning of problems, or of the effects of intervention, than do measures of health outcome. In addition, very few health outcomes are specific to environmental exposures, and individual health effects can often be traced back to many different exposures. Exposure-side indicators are therefore likely to give more specific information on where action can be taken to intervene.

Most exposure-side indicators presented here are based on regulatory standards and often expressed as numbers of exceedances of a pre-defined threshold, especially those relating to air and water quality. As such, the indicators are only directly interpretable in terms of population health risk if these thresholds are valid in terms of health effect (i.e. if true exposure thresholds occur, at or close to these levels) and if the number of exceedances is correlated with the overall levels of exposure and risk. For various reasons, this is often not true. Biases in the distribution of monitoring sites, for example - which are often located in areas known or suspected to be hotspots, in order to detect non-compliance with regulatory limits - may mean that the number of exceedances gives a poor indication of exposure or risk. More fundamentally, the association between the frequency and magnitude, or intensity, of environmental hazards is often strongly nonlinear (Smith, 1996), so that the number of exceedances is not proportional to either the number of people exposed or overall health impact. For all these reasons, interpretation of such indicators needs to be done with care. 
Similar problems, it has to be said, can occur with many of the health-side indicators used in these programmes. For the most part, these are based on the prevalence, or incidence, of mortality or morbidity. They thus take no direct account of disease severity or duration.

Taken together, these findings suggest that current indicator sets provide only a partial view of environmental health issues in the areas concerned, and are likely to provide a somewhat uncertain basis for policy development and assessment. One way in which they might be improved would be to frame the indicators in terms of the environmentally attributable health impact, for example in the form of disability adjusted life years (DALYs). These combine the burden due to premature death and disability into a single index (Murray and Lopez 1999) so that results can be compared and communicated in a standardised way. The DALY concept was introduced by the World Bank in the early 1990s (World Bank, 1993) and subsequently has been used to quantify environmental health impacts worldwide (Prüss-Üstün and Corvalán, 2006). A clear advantage is that DALYs enable different disease outcomes, or different exposures and pathways, to be aggregated and compared, and therefore assist in the evaluation of alternative interventions and prioritisation of policy actions. There disadvantage is that, to compute DALYs, data are needed not only on the distribution of exposures across the population, but also exposure-response relationships, relative disease severity, and the age and gender profile of the exposed population. Uncertainties in all these terms can undermine the credibility of DALYs in the eyes of policy-makers - notwithstanding the paradox that even larger, and less explicit, uncertainties arise when, as an alternative, these comparisons and aggregations are made intuitively, by the policy-makers themselves. It is also sometimes claimed that DALYs are difficult to interpret because of their abstract nature. It needs to be stressed, however, that all indicators are, by their very nature, abstractions, and the most informative indicators are likely to be those that enable all the important attributes of an effect to be brought together in a single, comparable, and reproducible measure.

Another, emerging technology that can help to combine data on different exposures and/or effects is biomonitoring data. In recent years, methods for biomonitoring have advanced considerably, allowing the measurement and interpretation of a range of different agents, in different human body tissues or fluids, and their interpretation as either markers of exposure or potential health effect (Becker et al., 2003, Smolders et al., 2009). For example, hair can be tested to determine past exposure to organic mercury - a biomarker of exposure (Choi and Grandjean, 2008), while saliva has been used to quantify cholinesterase activity, a biomarker for potential neurotoxic effects (Henn et al., 2006, Wang et al., 2008). Only one example of using biomonitoring as the basis for an indicator was found in the programmes reviewed here - the use of blood cotinine to indicate exposure to nicotine as a marker of children's second-hand smoke exposure. This may partly be because of the relatively novel status of biomonitoring, which means that routine and representative data sets have only just started to appear, and that its potential is not yet fully appreciated. At the same time some of the limitations of the technology need to be acknowledged. In particular, biomonitoring is an invasive technology, so is expensive to run, especially at the national or international scale, and raises important ethical considerations.

It is also notable that the programmes included in this review rarely used group-specific EHIs - for example, indicators that assessed risks to, or health status of, the most vulnerable members of society (such as children, the elderly, those who are chronically ill or economically disadvantaged and indigenous peoples). Numerous studies have shown that children are particularly affected by harmful environmental exposures because of a range of factors including their levels of mobility, eating patterns, behaviour, oxygen consumption and rapid development rates (Bearer, 1995). The elderly are likewise vulnerable because of their decreased mobility, changes in physiology and a more limited access to resources. These can limit their adaptive capacity, especially to temperature extremes such as heat waves (Koppe et al., 2004) and inadequate housing conditions which can 
result in a higher risk of accident and injury (Braubach and Power, 2011). Vulnerable subpopulations thus tend to make up a large proportion of the overall burden of disease: for example, the per capita number of healthy life years lost to environmental risk factors is about five times higher in children under the age of five years than in the total population (Prüss-Üstün and Corvalán, 2006). Focusing on these groups in EHI programmes can have thus benefits, not only by indicating who is most at risk and where action is most urgently needed, but also by giving an indication of inequalities in risk and health status within the population. In this way it can help to raise alternatives to simple, utilitarian principles in policy debates, and help promote actions to issues of environmental injustice (Brulle and Pellow, 2006, Kruize et al., 2007).

Perhaps the most notable finding of this review, however, is that there are very few broad-scale operational EHI programmes. This is in marked contrast to the area of environmental policy, where indicator sets are extensively maintained and used - for example by the European Environment Agency (2012), Organisation for Economic Development and Co-operation (2008), the World Resources Institute (2012), the Environmental Change Network (2012) and the United Nations Environment Programme (2012). Moreover, with the exception of Mexico, all the EHI programmes that do exist are confined to more developed areas of the world: to North America, Europe and Australasia. Since the WHO first promoted the concept of EHIs, substantial effort has gone into encouraging their development and use, and into establishing criteria and methods for their construction (e.g. Corvalán et al., 1996, Corvalán et al., 2000a, Briggs, 1999, Briggs, 2003b, Ahmed et al., 2007, English et al., 2009). At the same time, the particular need for action in the developing world has become all too apparent. According to estimates made by the WHO (2006), these areas account for approximately $90 \%$ of the total environmentally attributable burden of disease, in terms of DALYs (from approximately $70 \%$ of the world population). The potential gains of using indicators to help prioritise actions and support policy in these areas has also been emphasised (Briggs 2003). Nevertheless we found no regional, national or international indicator programmes in these areas. This would seem both surprising and regrettable. That environmental exposures and related health outcomes are not being routinely reported almost inevitably hampers progress in setting policy, targeting action, allocating resources in these areas, and makes it difficult to judge the effectiveness of the policy and other interventions that are introduced.

Reasons for this situation are no doubt varied. By focusing on national and regional programmes, for example, we have ignored more local initiatives. As the HEADLAMP programme (Corvalán et al., $2000 \mathrm{~b}$ ) demonstrated, EHIs can be especially powerful tools for informing local authorities and empowering local communities at this scale. We also need to recognise that we may have missed some broader-scale programmes. This, however, serves to highlight some of the inadequacies that exist in the availability of relevant metadata - i.e. information about the data. Two crucial types of metadata are important in this respect: 'discovery' meta-data (that which helps potential users find out about relevant information sources) and 'descriptive' metadata (that which provides technical details on those sources). Here, our main sources of both have been via the Internet, including both formally published and unpublished sources. Without some form of independent search, to reveal initiatives that we did not find, it is of course impossible to evaluate the quality or completeness of the discovery metadata (e.g. web-pages, published reports, peer-reviewed papers). The paucity of the available descriptive metadata is nevertheless evident. With the exception of the NEPHTN which provides an online template giving a wide range of technical details (e.g. derivation of measures, geographic scale, time period, rationale, use of the measure, limitations and data sources) - it proved difficult to obtain descriptive information about the indicators, and attempts to contact personnel from the programmes (or their data suppliers) were not always successful. This inevitably limits the use of the indicators and acceptance of their validity, both by scientists and policy-makers.

One further gap in this review needs to be highlighted. This concerns the extent to which the indicators are actually used, and to what effect, as the material effects of EHIs are often difficult to 
be seen. Information on indicator usage is not readily available, and there seem to have been few attempts to track the consequences of the $\mathrm{EHI}$ initiatives through the policy process to show their effect either on decisions or health outcomes. The NEPHTN, however, does provide a series of success stories outlining how public health officials have applied the indicators to identify trends and how decisions about public health actions have thus been made more quickly and easily (Centers for Disease Control and Prevention, 2011). Each story begins with an outline of the problem, what the tracking network contributed and how it improved public health. As a means of demonstrating the potential benefits of better information on environmental health, these case studies are undoubtedly useful. The results are nevertheless likely to be biased, in that success stories are deliberately selected; there still remains, therefore, the need for a more balanced and comprehensive assessment of the costs and benefits of $\mathrm{EHI}$ initiatives.

As noted earlier, the development of EHIs are intended to serve several purposes, one of which is to help support and prioritise policy and decision-making. To do this, clear and relevant information is required and one way to present this is through indicators. The implications of our findings have specific relevance to each of the six categorical domains within EHIs (Table 1). For example, the well-established water and sanitation domain implies that national funding and agency leadership is likely available for monitoring. Thus, inclusion of water-related EHIs in emerging programmes is recommended. Further research into the role of EHIs in decision-making, and their contribution to health outcomes, would certainly seem merited. It is axiomatic that information alone is not the answer to problems of environmental health. This information has to be used to change policyand this requires positive attitudes towards information amongst policy-makers. Achieving this is not easy and does not come automatically, for it typically involves a fundamental shift in the cultures, structures and procedures of governance, away from one that is essentially power-based towards one that is open and shared (Renn, 2005). EHIs thus imply the willingness of decisionmakers to yield some of their authority, and to trust the messages that science can provide. This can be a difficult and fearsome step for many government agencies. Environmental Health Indicators can also be used 'bottom up' to influence policy and decision-makers and as Briggs (2003) notes, in the hands of empowered and passionate people, EHIs can be used as powerful symbols to lobby and raise awareness of issues and concerns. As with other innovations, therefore, clear evidence is needed to show that EHIs really work, not only to make decision-making easier but actually to improve public health, if they are to be developed, adopted and used effectively. Good demonstration projects, showing not only how to develop indicators, but also how to apply them as part of decision-making and the benefits they may bring (for example, in terms of reduced inequalities or morbidity and mortality rates), are crucial in this respect. Likewise, it should be a prerequisite of any EHI programme to include a properly conceived monitoring project, aimed at evaluating its consequences.

\section{Conclusions}

The review conducted here has shown that there are, as yet, very few operational indicator programmes at the national or broad regional scale, in the area of environmental health. Those that do exist are focused mainly on developed countries. The indicators included in the programmes are also limited both in terms of their position in the causal chain and in terms of their thematic scope. Most are exposure-side indicators, and many tend to focus on air and water quality. Uncertainties in the exposure-response relationships that they imply, and the partial nature of the indicators, also means that they cannot easily be translated into an interpretable measure of health impact; this limits their ability to provide summative indications of the overall severity or importance of environmental hazards, or the net effects of policy intervention. In addition, the he extent to which any of the indicators are used in policy-making, and the implications in terms of policy effectiveness, are largely unknown. 


\section{References}

Ahmed, A. K., Ferring, A. \& Ruiz, L. I. (2007), Manual on Environmental Health Indicators and Benchmarks: Human Rights Perspectives, AAAS Science and Human Rights Program, Washington, D.C.

Bearer, C. F. (1995), "Environmental Health Hazards: How Children Are Different from Adults", The Future of Children: Critical Issues For Children and Youths, Vol. 5 No.2, pp.11-26.

Becker, R., Brozena, S. \& Smith, D. (2003). What is Biomonitoring? available at: http://www.americanchemistry.com/s acc/bin.asp?CID=257\&DID=1584\&DOC=FILE.PDF (accessed 12 May 2011).

Best, E. P. H. (ed.), (1983), Ecological indicators for the assessment of the quality of air, water, soil, and ecosystems, Kluwer Academic Publishers, Dordrecht.

Biosecurity Council. (2003), Tiakina Aotearoa Protect New Zealand: The Biosecurity Strategy for New Zealand, Viewpoint Communications, Wellington.

Braubach, M. \& Power, A. (2011), "Housing Conditions and Risk: Reporting on a European Study of Housing Quality and Risk of Accidents for Older People", Journal of Housing For the Elderly, Vol. 25 No.3, pp.288-305.

Briggs, D. (1999), Environmental Health Indicators: Framework and Methodologies, World Health Organization, Geneva.

Briggs, D. (2003a), "Environmental pollution and the global burden of disease", British Medical Bulletin, Vol. 68 No.1, pp.1-24.

Briggs, D. (2003b), Making a Difference: Indicators to Improve Children's Environmental Health, World Health Organization, Geneva.

Brulle, R. J. \& Pellow, D. N. (2006), "Environmental justice: human health and environmental inequalities", Annual Review of Public Health, Vol. 27, pp.103-124.

Cairns, J., McCormick, P. V. \& Niederlehner, B. R. (1993), "A proposed framework for developing indicators of ecosystem health", Hydrobiologia, Vol. 263 No.1, pp.1-44.

Centers for Disease Control and Prevention. (2010a). "Indicators and data", available at: http://ephtracking.cdc.gov/showIndicatorsData.action (accessed 13 December 2010).

Centers for Disease Control and Prevention. (2010b). "National Environmental Public Health Tracking Program", available at: http://www.cdc.gov/nceh/tracking/ (accessed 13 September 2010).

Centers for Disease Control and Prevention. (2011). "National Environmental Public Health Tracking: Tracking success stories", available at: http://www.cdc.gov/nceh/tracking/successstories.htm (accessed 22 November 2011).

Centre for Public Health Research \& GeoHealth Laboratory. (2011). "Welcome to the Environmental Health Indicators website", available at: http://www.ehi.ac.nz/ (accessed 24 November 2011).

Choi, A. L. \& Grandjean, P. (2008), "Methylmercury exposure and health effects in humans", Environmental Chemistry, Vol. 5, pp.112-120. 
Commission for Environmental Cooperation. (2006), Children's health and the environment in North America: A first report on available indicators and measures, Commission for Environmental Cooperation, Montreal.

Corvalán, C., Briggs, D. \& Kjellström, T. (1996), "Development of Environmental Health Indicators", in Briggs, D., Corvalan, C. \& Nurminen, M. (ed.), Linkage Methods for Environment and Health Analysis: General Guidelines, United Nations Environment Programme, United States Environmental Protection Agency, and World Health Organization, Geneva, pp. 19-53.

Corvalán, C., Briggs, D. \& Kjellström, T. (2000a), "The need for information: environmental health indicators", in Corvalán, C., Briggs, D. \& Zielhuis, G. (ed.), Decision-making in Environmental Health: From Evidence to Action, E\&Fn Spon, London, pp. 25-56.

Corvalán, C., Briggs, D. \& Zielhuis, G. (ed.), (2000b), Decision-making in environmental health: from evidence to action, E \& FN Spon, London.

Department of Human Services. (2008), Your health - a report on the health of Victorians 2007, State Government of Victoria, Melbourne.

Egorov, A. 2010. RE: Personal communication.

English, P. B., Sinclair, A. H., Ross, Z., Anderson, H., Boothe, V., Davis, C., Ebi, K., Kagey, B., Malecki, K., Shultz, R. \& Simms, E. (2009), "Environmental Health Indicators of Climate Change for the United States: Findings from the State Environmental Health Indicator Collaborative", Environmental Health Perspectives, Vol. 117 No.11.

Environmental Change Network. (2012). "Environmental indicators: climate change indicators and biodiversity indicators - climate change impacts", available at: http://data.ecn.ac.uk/environmental indicators.asp (accessed 20 February 2012).

European Environment Agency. (2012). "Indicators and fact sheets about Europe's environment", available at: http://www.eea.europa.eu/data-andmaps/indicators\#c7=all\&c5=human\&c0=10\&b start $=0$ (accessed 5 February 2012).

France, J. \& Briggs, D. J. (1980), "Environmental mapping of the European community: A review of the proposed method", Journal of the Operational Research Society, Vol. 31 No.6, pp.485496.

Healy, R. G. (1987), "'State of the Environment", Reports", Journal of Planning Literature, Vol. 2 No.3, pp.262-272.

Henn, B. D., McMaster, S. \& Padilla, S. (2006), "Measuring cholinesterase activity in human saliva", Journal of Toxicology and Environmental Health, Part A, Vol. 69, pp.1805-1818.

Kjellström, T. \& Corvalán, C. (1995), "Framework for the development of environmental health indicators", World Health Statistics Quarterly, Vol. 48 No.2, pp.144-54.

Koppe, C., Jendritzky, G., Kovats, R. S. \& Menne, B. (2004), Heat waves: risks and responses, World Health Organization Regional Office for Europe, Copenhagen.

Kruize, H., Driessen, P. P. J., Glasbergen, P. \& van Egmond, K. N. D. (2007), "Environmental equity and the role of public policy: Experiences in the Rijnmond region", Environmental Management, Vol. 40 No.4, pp.578-595.

Liu, B.-C. 1975. Quality of life indicators in the US Metropolitan Areas, 1970: A comprehensive assessment, Washington, Washington Environmental Research Center, U.S. EPA.

Ministry of Health. (2005), Drinking-water Standards for New Zealand 2005, Ministry of Health, Wellington.

Ministry of Health. (2009), Environmental Health Indicators for New Zealand 2008, Ministry of Health, Wellington.

National Academy of Sciences 1975. Planning for Environmental Indices, Washington, National Academy of Sciences.

Organisation for Economic Development and Co-operation. (2008), OECD Key Environmental Indicators 2008, OECD, Paris. 
Phillips, D., Khan, R. \& Hill, P. (2001), Environmental health indicators for New Zealand: the development and implementation of a core dataset, Institute of Environmental Science and Research, Wellington.

Prüss-Üstün, A. \& Corvalán, C. (2006), Preventing disease through healthy environments: towards an estimate of the environmental burden of disease, World Health Organization, Geneva.

Public Health Agency Canada. 19 November 2010. RE: Personal communication.

Rao, M., Prasad, S., Adshead, F. \& Tissera, H. (2007), "The built environment and health", The Lancet, Vol. 370 No.9593, pp.1111-1113.

Renn, O. (2005), Risk Governance: Towards an Intergrative Approach, International Risk Governance Council, Geneva.

Rice, J. (2003), "Environmental health indicators", Ocean and Coastal Management, Vol. 46 No.3, pp.235-259.

Smith, K. 1996. Environmental hazards: Assessing risk and reducing disaster, London, Routledge.

Smolders, R., Schramm, K.-W., Nickmilder, M. \& Schoeters, G. (2009), "Applicability of non-invasively collected matrices for human biomonitoring", Environmental Health, Vol. 8 No.8.

Spiegel, J. M., Bonet, M., Yassi, A., Molina, E., Concepcion, M. \& Mast, P. (2001), "Developing Ecosystem Health Indicators in Centro Habana: A Community-based Approach", Ecosystem Health, Vol. 7 No.1, pp.15-26.

United Nations Environment Programme. (2012), UNEP Year Book 2012: Emerging issues in our global environment, UNEP, Nairobi.

United States Environmental Protection Agency. (2010a). "National Ambient Air Quality Standards (NAAQS)", available at: http://www.epa.gov/air/criteria.html (accessed 2 November 2010).

United States Environmental Protection Agency. (2010b). "Summary List of Measures", available at: http://www.epa.gov/envirohealth/children/measures/index.html (accessed 6 December 2010).

Wang, J., Timchalk, C. \& Lin, Y. H. (2008), "Carbon nanotube-based electrochemical sensor for assay of salivary cholinesterase enzyme activity: An exposure biomarker of organophosphate and nerve agents", Environmental Science \& Technology, Vol. 42 No.7, pp.2688-2693.

World Bank. (1993), World Development Report 1993: Investing in health, Oxford University Press, New York.

World Health Organization 1981. Development of indicators for monitoring progress towards Health for All by the year 2000, Geneva, WHO.

World Health Organization Regional Office for Europe. (2010). "ENHIS fact sheets 2009", available at: http://www.euro.who.int/en/what-we-do/data-and-evidence/environment-and-healthinformation-system-enhis/publications/2009/enhis-facts-sheet-2009 (accessed 15 June 2010).

World Resources Institute. (2012). "Climate Analysis Indicators Tool (CAIT)", available at: http://cait.wri.org/ (accessed 20 February 2012). 


\section{About the authors}

Catherine Tisch

Catherine Tisch is a Research Assistant at the University of Edinburgh where she is interested in adolescent access to tobacco and alcohol retail outlets across Scotland and associated health behaviours, and socioeconomic/geographical inequalities in air pollution across Europe. Her previous research in New Zealand has included public health surveillance, monitoring and identifying trends in notifiable disease cases, and contributing to the New Zealand Environmental Health Indicator programme.

\section{Amber L. Pearson}

Amber L. Pearson is a Research Fellow on the Burden of Disease Epidemiology, Equity and Cost-Effectiveness Programme $\left(\mathrm{BODE}^{3}\right)$ and an Adjunct Fellow in the Department of Geography at the University of Canterbury. Her work includes water quality and quantity research in Uganda, built environment and air pollution research in the USA, and social and environmental determinants of community health in New Zealand. A current focus in her work involves the paradox of poor social and environmental conditions yet positive community health outcomes, or resilient places.

\section{Simon Kingham}

Simon Kingham is a Professor of Geography and Director of the GeoHealth Laboratory at the University of Canterbury, Christchurch, New Zealand. He has worked extensively in the areas of sustainable transport (and people's perceptions and attitudes to transport) and air pollution exposure and human health.

\section{Barry Borman}

Associate Professor Barry Borman is the Associate Director, Centre for Public Health Research, Massey University and is the principal investigator for the New Zealand Environmental Health Indicators programme. He has extensive experience in applied epidemiology and public health surveillance and been the Director of the New Zealand Birth Defects Monitoring Programme since 1986 From 2000-08, he was the Manager of Public Health Intelligence, the epidemiology and surveillance group of the New Zealand Ministry of Health.

\section{David Briggs}

David Briggs is Emeritus Professor in Environment and Health Science at Imperial College London, where he was a member of the Small Area Health Statistics Unit (SAHSU) and was responsible for geographical analysis and exposure assessment in epidemiological studies. He has worked extensively on both environmental and environmental health indicators for the World Health Organisation, European Commission and local authorities. He now lives in New Zealand. 